\title{
Leveraging Blockchain Technology for Halal Supply Chains
}

\author{
Marco Tieman* and Mohd Ridzuan Darun**
}

\section{Background}

Halal supply chains are vulnerable due to their credence quality attributes, importance of maintaining halal integrity throughout the supply chain, need to avoid doubt, lack of control of food norms, and sensitivity of the Muslim consumer towards halal. These vulnerabilities make halal supply chains complex to design, manage, and optimise. Transparency of halal supply chains is needed in order to ensure trust and authenticity of a halal brand. The principle of a shared database that is safe, open and verifiable without a central operator is an attractive proposition to embed trust and authenticity for halal food, cosmetics, home care, and pharmaceuticals.

Blockchain is the main technology behind Bitcoin. Blockchain is already called the Fourth Industrial Revolution. It is a digital public ledger comprising stringed data blocks containing information, similar to our DNA. It is not stored somewhere centrally, but distributed on many servers throughout the world. Blockchains are encrypted and automatically synchronised in the distributed blockchains, making them a trusted public ledger that everyone can inspect, but no single user controls.

The combination of the distributed ledger technology with smart contracts, contracts between supply chain partners that ensure halal compliance in each link in the halal supply chain, has the potential to create high performance halal supply chain networks.

\section{What are the Challenges Facing Current Halal Supply Chains?}

A large discussion on halal blockchains was held on 15 May 2017 at Universiti Malaysia Pahang in Kuantan (Malaysia) organised by the Faculty of Industrial Management. This large discussion group showed that halal supply chains have inherent problems or flaws, namely in: (1) traceability (ability to verify the location of a product) and organising product recalls; (2) transportation and warehousing (storage) downstream of the supply chain in accordance with halal requirements; (3) end-to-end chain integrity (unbroken chain) from source to 
point of consumer purchase; (4) different halal systems and interpretations of different markets; and (5) lack of integration of information technology systems.

These problems require a radically different approach to how halal supply chains are orchestrated. Halal blockchains have the potential to solve all of the above halal industry problems!

\section{A Vision of Halal Supply Chains Through Blockchain Technology}

A halal blockchain would be a digital ledger of all halal supply chain transactions that have ever been executed. It would constantly grow as 'completed' blocks are added to it with each new set of transactions. The blocks are added to the blockchain in a linear, chronological order. Each node in the halal supply chain network gets a copy of the blockchain, which gets downloaded automatically upon joining the halal supply chain network. The halal blockchain has complete information about the addresses and their supply chain path right from source to the point of consumer purchase. As the halal blockchain database is shared by all nodes participating in a halal supply chain network, information is easily verified by just scanning the QR-code (a two dimensional barcode) on a product.

Blockchains pre-program the halal requirement of the destination market, such as: halal production certificate requirements, halal storage-transportationterminal handling terms, coding of halal on freight documents, and many more. In a blockchain you can easily identify the parties that committed fraud, as this remains visible. This discourages the industry to commit fraud in halal supply chains. At the same time it allows the rating of halal logistics service providers, distributors, and other supply chain participants based on the performance of their services.

\section{Halal Blockchain Design Principles}

The main objectives to be achieved with halal blockchains are: reliable data and trust in halal supply chains; seamless and efficient halal process from source to point of consumer purchase; sustainability of halal supply chains; consumer confidence in halal brands; and global recognition of halal blockchains.

The main principles of halal blockchains are: that halal blockchains incorporate the different Mazhabs of the destination market, in particular the Islamic schools of thought, fatwas (religious rulings), and local customs; halal blockchains should be relevant for both Muslim and non-Muslim countries; halal certification requirements of the destination market and mutual recognition be critical design principles for halal blockchains; supply chain participants be automatically aligned and informed on process compliance based on the specific product-market scenario; and authenticity and security of halal blockchains be 
a top priority to protect confidential information and minimise the chance and impact of cyber attacks.

Smart contracts are pre-agreed autonomous programs that define supply chain relationships as well as automatic actions. In the case of halal issues, the blockchain system would trigger automatic immediate action based on the smart contract's terms, for example, initiating a product recall, internal and external communication, informing of halal authorities, etc. Automatic action reduces lead-times in resolving halal issues, thereby reducing reputation damage.

Performance measurement of halal supply chains and their participants is critical to ensure high performance. This requires first of all a classification of halal blockchain participants in terms of a halal assurance system; local and international halal certification; and whether a halal assurance system is in place or not. Second, the actual halal performance needs to be measured in areas of efficiency, effectiveness, and robustness.

Manufacturers, brand owners, and retailers benefit from halal blockchains, in particular through transparency of supply chain, synergy advantages through vertical and horizontal collaboration, standardisation of halal assets, and more effective risk and reputation management. Logistics service providers and distributors benefit from halal blockchains too, in particular through long term customer relations, better use of halal assets, consolidation of halal cargo and new value added logistics and services, digitalisation of paper flows, and more efficient payment settlement. Halal certification bodies benefit through easy auditing of halal supply chains and faster support for industries in case of a halal issue or crisis.

\section{Conclusion and Recommendations}

Halal blockchains provide clear advantages for manufacturers, brand owners, retailers, logistics service providers, distributors, and halal certification bodies. For better trust and authenticity, a country's halal brands and halal certification bodies should embrace this new technology to support the halal industry in case of a halal issue, or worse, a halal crisis. They should support the halal certification of logistics service providers, distributors and retailers in order to facilitate a higher compliance in transportation and warehousing downstream of the supply chain. Harmonisation and standardisation of halal supply chain standards in different jurisdictions will be essential in the coming years to better support halal industries and their global supply chains. 


\section{Notes}

* Marco Tieman is Adjunct Professor with the Faculty of Industrial Management, Universiti Malaysia Pahang (Malaysia). He obtained his Master's degree in industrial engineering (logistics) with the University of Twente (the Netherlands) in 1997 and his $\mathrm{PhD}$ in business management (halal supply chain management) with Universiti Teknologi MARA (Malaysia) in 2013. He is also the CEO of LBB International, an international supply chain management consultancy and research firm specialising in halal purchasing and supply chain management. He chaired the development of the International Halal Logistics Standard (IHIAS, 0100:2010) under ICCI-IHI Alliance. Dr. Marco Tieman is the corresponding author and can be contacted at: marco@lbbinternational.com.

** Mohd Ridzuan Darun is the founding Dean of the Faculty of Industrial Management (FIM), Universiti Malaysia Pahang (Malaysia). He is an expert in Management Accounting, Management Control System, Halal Supply Chain, Working Capital Management and Risk Management. He obtained his Bachelor of Science in Finance (majoring in corporate finance and investment) from Southern Illinois University at Carbondale, USA, Master of Business Administration from Universiti Utara Malaysia, and a PhD in Accounting from Lincoln University, New Zealand. Under his leadership, FIM has achieved international accreditation from ABEST21 and is working towards CILT UK Accreditation. He also created a new Governance and Integrity Research Unit and a start-up learning factory within FIM. Furthermore, he has also established seven new collaborations with related international and domestic institutions. He can be contacted at: mridzuand@ump.edu.my. 